Relations industrielles

Industrial Relations

\title{
Employer-Employee Relationship in the Modern Industrial
}

Business

\section{Trends Study}

\section{Jean Gagné}

Volume 5, numéro 7, avril 1950

URI : https://id.erudit.org/iderudit/1023363ar

DOI : https://doi.org/10.7202/1023363ar

Aller au sommaire du numéro

\section{Éditeur(s)}

Département des relations industrielles de l’Université Laval

\section{ISSN}

0034-379X (imprimé)

1703-8138 (numérique)

Découvrir la revue

Citer cet article

Gagné, J. (1950). Employer-Employee Relationship in the Modern Industrial Business: Trends Study. Relations industrielles / Industrial Relations, 5(7), 67-70. https://doi.org/10.7202/1023363ar

Tous droits réservés @ Département des relations industrielles de l’Université Laval, 1950
Ce document est protégé par la loi sur le droit d'auteur. L'utilisation des services d'Érudit (y compris la reproduction) est assujettie à sa politique d'utilisation que vous pouvez consulter en ligne.

https://apropos.erudit.org/fr/usagers/politique-dutilisation/ 


\section{EMPLOYER - EMPLOYEE RELATIONSHIP IN THE MODERN INDUSTRIAL BUSINESS}

Trends study

Jean Gagne

If we place ourselves on the level of relations which exist in the enterprise between the workers and their job, the workers among themselves, the workers and general working conditions, the workers and authority in the enterprise, we can come to some very interesting conclusions about employer-employee education towards an industrial democracy in our days.

In fact, if we consider a little the list just stated of the relations which tie the worker to the enterprise where he works, we see also the source of all the conflicts which exist in the industrial world. It is well recognized to-day that these are only a manifestation of the poor adaptation of the workers to their tasks and to their place of work, to deplorable working conditions, to poor relations between the management of the enterprise and the workers. Many American and Canadian experiences have shown these facts.

Now, in order to educate personnel by organizing sound human relations in the factory or shop or office, it is particularly important to discover means and methods to maintain peace and collaboration between management and labour. Besides, this peace and collaboration is recognized as a guarantee of maximum productivity.

But it has been experimentally established that this stage of peace and collaboration is reached only when there is a maximum of coordination between the workers and their work, a perfect adjustment of jobs to the workers, together with general working conditions which will lead to a greater efficiency and productivity of the personnel. The whole ensemble must be completed by a thorough coordination between the heads of production (i.e. the technical factor) and of personnel (i.e. the human factor).

Closely related to the problem of coordination, is the problem of collaboration. And the experience of a few decades has proved that there is a good and bad way to obtain collaboration of personnel in an industrial enterprise.

In spite of the fact that the science of organization of personnel is a relatively young science and that its improvement depends upon sciences such as Physiology, Economics and Sociology, not yet very well developed themselves, one may say that a certain number of principles and methods of procedure have already been discovered which permit some very interesting applications, such as: job analysis and job specifications; methods of recruiting, selecting and placing the workers, various methods of education and propaganda to stimulate the interest of the employees in their work; various ways found to arrive at a fair treatment to workers in all labour relations; the methods for studying and the ways found to reduce labour turnover; the methods and technical manners of fighting the dangerous results of absenteeism and tardiness, two recurrent plagues of industrial production; rational methods of transfers and promotions; scientific methods of training ordinary and supervisory personnel; social and economic security of the workers, profit-sharing plans, and so forth.

Furthermore, quite recently new sciences have been added to that of personnel organization which help it considerably to achieve its aims, such as psycho-physiology, a science which has as an object the study of the human factor in industry and the physiological and psychological conditions affecting man at work, and psycho-technics, a branch of the latter which has an object the study of tests which are used for the selection and placement of workers.

But in spite of all these scientific and technical efforts, we are far from having obtained the peace and collaboration desirable for the best possible progress of industry, of those interested in it, and of society. On the contrary, social and economic disturbances are more and more numerous. Would this not be because we have often forgotten to educate all the members of industry towards the full realization of the true aim of the industrial enterprise?

In fact, what is the goal of an economic organization in a capitalistic society, if it is not the direction of the greatest possible profit into the hands of the shareholders ? But even economists with capitalistic tendencies feel that the attempt to bring workers to collaborate in realizing such 
a goal in a laboristic society (in which we are living now) is quite idealistic and impossible. Experience has shown that the efforts made with the latest scientific procedures of education and propaganda to force workers and their unions to collaborate in this conspiracy of concentration of wealth in the hands of a few, have only brought conflicts and revolution, a struggle between management and workers, between Capital and Labour.

It seems that the only method to bring the workers to participate loyally and effectively towards the full realization of the true aim of industrial enterprise, is to make them real members of the enterprise, real partners in production. This can be brought about by the new techniques now being widely used in personnel administration and by the means of education more and more popularized in labor unions. Since the workers would be thus educated, one could make real partners of them by having them little by little share in the profits, and participate in the direction of the enterprise, in their proper degree. Wouldn't this, after all, be a more normal state of things ? Wouldn't it be a "fair deal"? An enterprise justifies itself, after all, by the service it renders to society.

Granting that the workers will be adequately educated for their proper dignity and new responsibility, this seems to be the only peaceful way to come to social peace in our turbulent industrial relations, to attain a real collaboration between Capital and Labour without destroying free enterprise. But a question comes naturally to our mind at this point in the discussion, and it is worth while giving it some consideration. Here it is: How have the employers and employees been led to study these new conceptions of industrial relations where priority is claimed for human capital over financial capital ? This, in my humble opinion, is due firstly to the experience which management has had in recent years regarding the part fulfilled by the human factor in production. Secondly it is due to the struggle carried on by the workers united in professional associations to conquer the place belonging to them in industry because they have become concious of their human dignity.

In fact, if we throw a rapid glance at the history of industrial relations, we note that it presents a concise résumé of the rise of the workers towards the place which rightfully belongs to them in society. The worker passed successively from the status of a slave as he was in antiquity to that of a man dependent but free with the beginning of the Christian era and especially during the Middle Ages, finally to that of a greater and greater economic freedom achieved in our era through professional association. The workers' associations gave to them principally contractual freedom, which, although still inadequate, is a clear witness of our progress towards an industrial democracy.

In many countries, particularly in Europe, the history of industrial relations teaches us that the conquests of the working class have been made by revolutions. Those capitalist countries which brought back the workers to the age of slavery, went through the worst. In America, progress towards sounder industrial relations has taken the character of an evolution, rather than revolution.

On the employer's side, the science of personnel administration with the dominant idea "of putting the right man in the right place", has done its part in the normal and pacific evolution of our industrial institutions. In the light of its principles, and of the facts and experience gleaned especially during the 2nd World War, industrial leaders and experts have now come to the conclusion that personnel administration is inseparable from industrial rationalization.

Thus it has been realized that the principle "put the right man in the right place", one basic principle of this new science of personnel administration, means that the man put in the place which best fits his physical and intellectual aptitudes, and which has the best possible working conditions, will be more efficient than the man tied to a task beyond his physical ability, carried out in an environment bad for his health, and under unfavourable working conditions.

Another principle which has become evident in the science of management is: it is necessary, in order to obtain from the workers the maximum effort, to permit them, whatever be their place in the enterprise, to realize fully their potentialities in life, in their work and, if possible, through their work.

From all this, it is clear that the duty of the administrator of labour relations, in order to achieve the greater good of the enterprise and of all its members, is to find a compromise between the logic of technique and the logic of human welfare; "to find the just means between the needs for a rational production determined by scientific standards, and the physical, intellectual and emotional needs of the workers". ${ }^{1}$

(1) Colard, MaHEu, L'organisation du personnel dans lindustrie, 6th edition, Dunod, Paris, 1946, p. 15. 
But this function can only be realized by educational influence among the members of the enterprises, as much among the members of management as among the workers, in order to give them a desire to work for the common welfare of all the members of the industry.

This influence must be an influence which frees the captains of industry from the dangerous narrowness of the following principle: an industry has only one end, to collect wealth, to bring the most possible profit to its shareholders and to its directors.

This influence must bring industrial leaders to realize that the well-being of all the workers, and the true social utility of the manufactured product or of the service rendered to the public are the principal factors which justify all the work of production. It is not only the owner of a furniture factory, and the rich merchant who buys its output, who have a right to sit on chairs, but also the workers who make the chairs. And they must be able to sit on them without giving up all the results of their work.

This influence must also develop among the employees a spirit of teamwork throughout the factory. This spirit does not grow by chance but is the result of a definite plan and constant efforts. It is necessary to develop the essential qualities of supervisory personnel, qualities which require a good training. The psychological knowledge of the labour class mentality would help greatly in this problem, on the condition that justice and truth guide the application of this knowledge.

Certainly a plan drawn beforehand will help to render effective and profitable the methods of education of the workers in order to discover the best ways to improve production and lower the cost, to stimulate the interest and the happiness of the worker in his work, and to manage properly the other elements which affect the entire gamut of labour relations. All these are necessary means which will to a greater or less extent promote industrial peace. But they will only be efficient if they are based on the understanding of the profound desire of the mass of contemporary workers, the natural desire to participate in the life of the enterprise, which they consider as a common work.

But what do the facts tell us ? What is the place that has been given to the workers in the organization and operation of the life of the en- terprise ? The last. For too long the worker's place has been at the bottom of the scale. And what has complicated the situation still more, is that some exploiters of human capital in industry have exerted themselves in many ways (even if they were human enough in others) to prove that this was the only place to which they had a right.

It is because of this narrow conception of the participation of the worker in the life of the enterprise, that the worker does not feel at home in the factory in which he lives eight (8) hours of the day, for there his spirit is continually suppressed in an atmosphere of insecurity and instability.

"The contemporary worker, the mass worker wants to find again the sense of achievement of his work in the common task. He wants to be at home in an enterprise which is also his enterprise." Does he not spend the better part of his life in the factory? Does he not feed into the machine the better part of his energy ? It seems to him that the business of the factory should be his business also in a certain way. He does not say so, he thinks it. He considers that he has the right to know the difficulties as well as the successes of the interprise. To go against the worker's aspiration is to work for nothing. THE WORK OF INTEGRATING THE WORKERS INTO SOCIETY MUST BE CARRIED ON WITHIN THE RANKS OF INDUSTRY ITSELF, ESPECIALLY BY THOSE WHO DIRECT MAN-POWER. It is necessary to make of industry a community of rights and duties amid a variety of functions.

And in our era, what makes the work of education in factories, shops, offices, public services, complex and difficult, is that "those who are in charge of the direction of theses enterprises are obliged to conciliate contradictory demands. These, on one hand, are the necessity of order, authority, discipline, the respect due to the legitimate rights of the proprietors, the function of the personal profit motive which cannot be replaced; on the other hand the new demands of the workers, the need of justice, of security, of this hidden desire to participate in the economy and direction of the enterprise. These demands must be satisfied within the framework of the enterprise by the establishment of more human relations between the employer and his employees in such a way that they feel really treated and considered

(2) LALOIRE, Marcel, Les relations sociales au sein des entreprises, Dunod, Paris, 1947, p. 18. 
as human beings, as collaborators in the enterprise." 3

If we approach personnel problems with another spirit, if we do not understand this responsibility which we have, if we do not grant this place to the personnel in industry, no real education would be possible among the workers. And the evolution or the revolution of the masses would find the employers and their representatives at fault.

At the present time, we often hear that in labour relations, we are beginning to live in the era of the integration of the workers into society by their participation on a larger scale in the control and administration of industry.

The education of the employers and employees in regard to their rsepective rights and duties in the pursuit of the common good of the enterprise has brought a social and economic evolution in labour relations with corporative organizations and new conceptions, such as parity committees, employee stock-holding formulas, profitsharing plans, conception of the enterprise as community of work, the desire expressed many times by the workers to participate fully in the life of the enterprise. Everywhere, one hears talk of obligatory structural reforms.

And, particularly in America, it is clear that we are in the presence of a vast effort on the part of all right-thinking persons to try to give a spirit and soul to existing institutions in order that they may really serve mankind. A "new look" in em-

\section{(3) Ibidem, p. 18.}

\section{LABOUR JURISPRUDENCE}

\section{Value of a union constitution - Mandamus}

A member of a union local - No. 1552 of the Shipliners Union - was found guilty of harbouring stolen goods and fined $\$ 25.00$. Following the sentence one of the union members proposed that the man be expelled. This the union voted down by a big majority. The president vetoed the majority decision of the members.

The Court of Appeals unanimously reversed the decision of the Superior Court. In its interpretation of the constitution of the union local the Court of Appeals decided that in the circumstances such a veto exceeded the powers granted to the president by the said constitution and that, therefore, the veto was illegal. The fact that the defendant had pleaded guilty before a criminal court ployer-employee education occupies the first place in this vast effort of social renovation.

A negative spirit cannot stop the mounting tide of these new ideas. It is exactly this spirit which refuses to understand the profound aspirations of the working classes, to analyse them in order to grant them what is fair in their desires, and to help them in their effort of social promotion, which has given room to the materialistic ideologies which are shaking the world at the present time.

In our country, we are on the threshold of this transformation of the industrial world. What attitude will the employers and their representatives take in this irresistible evolution of the working classes? What will be their part in the necessity of integrating workers in the structure of enterprises, to lead them to participate really in them ? By their abstinence will they let industry founder into the proletarian revolution or will they work with all their intelligence and all their force to save, in the new world, the rights and inalienable place of the employer in a system of free enterprise?

This is, in my humble opinion, the true problem which presents itself in all labour relations problems at the present time. Evolution or revolution. Systematic opposition to new ideas, or progressive education of the members of the enterprise and serious study of these new trends in labour relations.

Find the right solution to this problem an acceptable and applicable solution for all let us hope that this will be the triumph of human engineering in the troubled years ahead...

did not lead automatically to the loss of his membership in the union. Since then, in meeting actions of this sort, the court must maintain a writ of Mandamus and order the defendant reinstated in the union local.

Moreover it cannot be pretended that the Mandamus is ineffective against the union local because it is not incorporated, precisely on account of articles 28 and 29 of ch. 342 R.S.Q. (Special Procedures).

(Comtois, plaintiff, versus Union Local 1552 of the Shipliners, defendant, and that of Robillard and others cited in evidence; Judges Galipault, St-Germain, Barclay, Pratte and Casey; Montreal, May 28, 1948, cf. R.J. de Q., C.B.R., Nov. 48, p. 671.) 